\title{
A STUDY OF INTERSTATE VARIATIONS OF HEALTH OUTCOMES IN INDIA
}

KEY WORDS: Health, IMR, LEB and Socio-economic variables of health outcomes.

\section{Manju Devi*}

Ph.D Research Scholar, Dept. Of Economics, Himachal Pradesh University, Shimla. *Corresponding Author

\section{Prof. Sanju Karol Pro. of Economics ICEDOL, Himachal Pradesh University, Shimla.}

The present study attempts to highlight the trends and regional variations in health outcomes in major states of India. The study investigates the spatial variations across the selected states of India in terms of basic health indicators such as infant mortality rate(IMR), under five mortality rate (U5MR), life expectancy rate(LEB) and literacy rate. In order to capture the health outcomes of 20 major states of India spearman's rank correlation has been calculated. In the study, health outcomes data have been used forIMR trends in rural urban comparison for the period 1980 to 2017 .The study revealed the rank correlation between Life expectancy at birth( LEB) and poverty level, per capita NSDP, total literacy rate, per capita health expenditure show highly statistically significant correlations. Human Development Index (HDI) value and LEB also shows the rank correlation (0.809) which are highly statisticallypositively significantcorrelations. Negative signare (-0.275) of rank correlation betweenLEBand poverty level depicts the inverse relationship between them, showing an increase in poverty level is expected to bring a fall inLEB. The study revealed the Inequalities in the availability of health servicesacrossthe selectedstates of India. Variations are pronounced in terms of socio-economic, demographic and maternal health outcomes. The interstate variation are the best illustrated by comparing the state of Kerala with (7 per thousand live birth) in IMR and female literacy rate with (92.lpercent).Thestudy also focuses on the inequalities in utilization of preventive and curative servicesacross the rural -urban areas of selected states of Indiaand found that the economic conditions and effectiveness of health services at the state level have direct bearing on health status of people in the respective states.

\section{INTRODUCTION}

An inter-state analysis of trends and variation in health outcomes has attracted considerable interest on the part of economic researchers in the empirical levels. It is universally acknowledged that good health has intrinsic value and therefore constitutes an integral element of development. Development of any country is directly linked with the health indicators of people of the country. Health status is assessed on the basis of health outcomes of a population, reflected in such indicators as life expectancy at birth, infant mortality rates as well as incidence of morbidity and malnutrition. India's health outcomes have improved overtime because of extension of primitive, preventive and curative services to all section of the society. Despite falling child mortality, otherrates remain high as they are strongly related to child malnutrition where little progress has been made (Choudhary 2015).

However, on the other hand, (Baru2010) in their studies have found out a persistence and in some cases, the widening of inequities in health outcomes as well as access to health services in India, over the last two decades, the health policy document of 2002 and the sub documents have highlighted these concerns that statistics bring out the wide differences between the attainments of health goals, in the better performing states as compared to the low-performing states. It is clear that national averages of health indices hide wide disparities in public health facilities and health standards in different parts of thecountry. This observation is reinforced by some studies that show the growing inequalities in mortality and nutrition at all India level, across states, as well as within states and social groups. These groups have faced social and economic inequality that disadvantages themes of in term of access to resources and basic needs which is reflected in poor health outcomes.Rao 2007 in his analysis of financial variations shows that while per capita spending on health is Rs. 35.05 for Kerala and Rs. 42 for Tamil Nadu, it is abysmally low for Uttar Pradesh at Rs. 18.10 during 1998-99.

At the independence time, health circumstances in India were extremely poor with poor health care services which were unequal and much urban dependent than rural areas. But after independence India witnessed a remarkable progress in health sector. Bhore Committee,1946 on Health Policy was given first stepping stone in remodeling the health services in India. India's crude birth rate has come down from 40.8 in 1947 to 20.2 in2017 and crude death rate has also reduced from 27.4 to 6.3 per 1000 people. Infant Mortality Rate has declined from 146 in 1947 to 33.0 in the year 2017, while at the same time Life Expectancy at Birth has increased from merely 35 years in 1947 to 68.8 years in2016 (SRS,2018).

In global scenario, India's position in respect of health outcomes is not very impressive. Life expectancy at birth in India in the year 2017 is much below (68.8 years) than its neighboring countries, Bangladesh (72.8 year) and better than Pakistan (66.6 years) and Afghanistan (64.0 years). Infant Mortality Rate (IMR) per 1000 live births in Pakistan (64.2) and Afghanistan (53.2) which is higher from India i.e. (34.6) and on the other side with better position in IMR comparison to India like China (8.5), and U.S. (5.6) in the year 2016 (UNDP,2016).

Table 1: Health Indicators Among Selected Countries

\begin{tabular}{|l|l|l|l|l|}
\hline Country & $\begin{array}{l}\text { Total } \\
\text { Health } \\
\text { Expenditu } \\
\text { re } \\
\text { Percentag } \\
\text { e of GDP } \\
\text { On Health } \\
\text { (2015) }\end{array}$ & $\begin{array}{l}\text { IMR(2016) } \\
\text { Per 1000 }\end{array}$ & $\begin{array}{l}\text { UMRR } \\
\text { Live Birth }\end{array}$ & LEB (2017) \\
\hline Us & 16.8 & 5.6 & 6.5 & \\
\hline Germany & 11.2 & 3.2 & 3.8 & 81.2 \\
\hline U. K. & 9.9 & 3.7 & 4.3 & 81.7 \\
\hline Japan & 10.9 & 2.0 & 2.7 & 83.9 \\
\hline Canada & 10.4 & 4.3 & 4.9 & 82.5 \\
\hline China & 5.3 & 8.5 & 9.9 & 76.4 \\
\hline India & 3.9 & 34.6 & 43.0 & 68.8 \\
\hline Pakistan & 2.7 & 64.2 & 78.8 & 66.6 \\
\hline Bangladesh & 2.6 & 28.2 & 34.2 & 72.8 \\
\hline Nepal & 6.1 & 28.4 & 34.5 & 70.6 \\
\hline Afghanistan & 10.3 & 53.2 & 70.4 & 64.0 \\
\hline Myanmar & 4.9 & 40.1 & 50.8 & 66.7 \\
\hline Bhutan & 3.5 & 26.8 & 32.4 & 70.6 \\
\hline
\end{tabular}

Source:HDR Report 2016 


\section{Review Of Literature}

There is a large volume of empirical literature to scrutinize the linkages of health system and socio economic factors with health outcomes. Kurian(2010) assessed the overall condition and health outcomes in different states of India. The health indicators of India were quite unimpressive and there exist vast disparities in the achievement of health outcomes across the regions of the country, between the genders. The basic weakness is the absence of accessible basic doctors. Over eighty percent of health expenditure in the county is borne by the household as out-of pocket expenditure. The study found that the richest quintile enjoy three times the share of public subsidy for health care compared to the poorest quintile and limited public expenditure on health care are regressively distributed among the people of the country. The country have yet to take-up the challenges of public health sanitation, potable water, housing, food security, and working environments all these were important aspect of public health, where coordinated action by all concerned were essential to achieve better health outcomes. Female literacy, women empowerment, community action, antenatal and continuous monitoring of the health parameter of the infants, quality of drinking water and sanitation were all equally important for fighting against malnutrition. India needs to strengthen the publicity funded primary healthcare services with universal coverage and no user charges.

Amonker And Brinker (1997) has explained the role of various socio-economic factors that influenced infant and child mortality in different states of India, 23 socio-economic variables have been taken from NFHS-1 data, which have been then grouped into 4 major categories such as educational, modernization, health and family planning variables. The dependent variables in their study are infant mortality and child mortality rate. Three statistical tests that have been used the Pearson's correlation coefficients, Spearman's correlation coefficients and multiple regression analysis. Their results showed that higher socio-economic development ensured lower IMR and CMR among Indian states.

The interstate variations in availability of healthcare services across 15 major states of India which have been categorized as high, middle and low income states according to their per capita income has analyzed by Purohit (2004). On the basis of data by NSSO ( $52^{\text {nd }}$ round) has concluded that there exists an inequality in health care resources favoring the high income states.

However, poor in the rich states were also not in favorable situation in terms of overall distribution of healthcare services.In case of Out Patient Department (OPD) treatment and impatient care, there was high financial burden for low income states than the other states. The study emphasized on mobilization of additional resources through the assistance of donor agency to overcome regional disparities in healthcare across the different states of India.

The rest of the paper organized as follows. Section 2 presents the data sources and methodology are discussed and section 3 presents the inter-state variation and inequalities in health outcomes section 4presents the inequities in health services in terms of availabilityandinequalities in utilization of preventive and curative services and section 5 presents the results of the study. Finally, the conclusion can be found in Section 6 .

\section{DATA SOURCES AND METHODOLOGY}

For the purpose of this study, secondary data has been used. The data has been collected from various issues of SRS bulletin, International Institute of population science (IIPS)NFHS, Registrar General of India and planning commission of India and National health Profile, Central statistical office (CSO), GOI.

\section{Objectives of the study}

1. To analyze the inter-state trends and variation in health outcomes.

2. To study the inequalities in availability of health services across the selected states of India.

In order to capture the association among the health outcomes variables of 20 major states of India spearman's rank correlation has been used. In order to significance of rank correlation coefficients of different indices for different states, empirical value of has been computed,

$$
\mathrm{t}=\mathrm{rR} \sqrt{n-k} / \sqrt{1-r R 2}
$$

Where t distribution has $n-k$ degrees of freedom.

Spearman's rank correlation has been done to explore the correlations among the ranking of the states on the basis of health outcomes variables along with IMR and U5MR. For the purpose of analysis twenty major states of India has been considered. The null and alternative hypothesis have been formed which are as follows:

HO: There is no significant difference in the ranking of the states given on the basisof health outcomes variables.

$\mathrm{Hl}$ : There is significant difference in the ranking of the states given on the basis of health outcomes variables.

\section{TRENDS OF IMR IN INDIA}

In recent years the rate of decline in IMR trends has been stagnated making it difficult to achieve the millennium development goal of child mortality (Subburamn 2015). According to SRS reports, India has reduced its IMR trends in the years 1980 was 114 to 33 by 2017 . Between 2004 and 2008 the average decline of IMR trends has been about 1 Percent per year. Had India maintained the long term trend achieved till early nineties, the observed rate would have been much less today, implying of many infants. It is expressed from the data of IMR trends since 1980 to 2017 that the rural urban differences in IMR trends have been continuing for a long time. More female infants die as compare to males. It is seen in the Year 2017 female IMR is at 34, whereas male IMR is 32 per thousand live births.

IMR

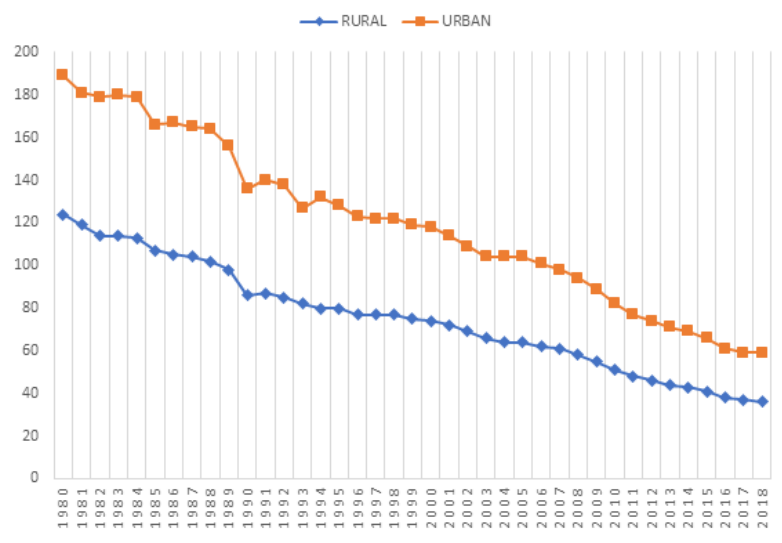

Figure: 1 IMR IN INDIA 1980-2018

Table 2: Trends of India's IMR

\begin{tabular}{|l|l|l|l|l|l|}
\hline Year & Total & Male & Female & Rural & Urban \\
\hline 1980 & 114 & 113 & 115 & 124 & 65 \\
\hline 1981 & 110 & - & - & 119 & 62 \\
\hline 1982 & 105 & 106 & 104 & 114 & 65 \\
\hline 1983 & 105 & 105 & 105 & 114 & 66 \\
\hline 1984 & 104 & 104 & 104 & 113 & 66 \\
\hline 1985 & 97 & 96 & 98 & 107 & 59 \\
\hline 1986 & 96 & 96 & 97 & 105 & 62 \\
\hline 1987 & 95 & 95 & 96 & 104 & 61 \\
\hline
\end{tabular}


PARIPEX - INDIAN JOURNAL OF RESEARCH | Volume - 10 | Issue - 03 |March - 2021 | PRINT ISSN No. 2250 - 1991 | DOI : $10.36106 /$ paripex

\begin{tabular}{|c|c|c|c|c|c|}
\hline 1988 & 94 & 96 & 94 & 102 & 62 \\
\hline \begin{tabular}{|l|}
1989 \\
\end{tabular} & 91 & 92 & 90 & 98 & 58 \\
\hline 1990 & 80 & 78 & 81 & 86 & 50 \\
\hline 1991 & 80 & 81 & 80 & 87 & 53 \\
\hline 1992 & 79 & 79 & 80 & 85 & 53 \\
\hline 1993 & 74 & 73 & 75 & 82 & 45 \\
\hline 1994 & 74 & 75 & 73 & 80 & 52 \\
\hline \begin{tabular}{|l|}
1995 \\
\end{tabular} & 74 & 73 & 76 & 80 & 48 \\
\hline 1996 & 72 & 71 & 73 & 77 & 46 \\
\hline 1997 & 71 & 70 & 72 & 77 & 45 \\
\hline 1998 & 72 & 70 & 73 & 77 & 45 \\
\hline 1999 & 70 & 70 & 71 & 75 & 44 \\
\hline 2000 & 68 & 67 & 69 & 74 & 44 \\
\hline 2001 & 66 & 64 & 68 & 72 & 42 \\
\hline 2002 & 63 & 62 & 65 & 69 & 40 \\
\hline 2003 & 60 & 57 & 64 & 66 & 38 \\
\hline 2004 & 58 & 58 & 58 & 64 & 40 \\
\hline 2005 & 58 & 56 & 61 & 64 & 40 \\
\hline 2006 & 57 & 56 & 59 & 62 & 39 \\
\hline 2007 & 55 & 55 & 56 & 61 & 37 \\
\hline 2008 & 53 & 52 & 55 & 58 & 36 \\
\hline 2009 & 50 & 49 & 52 & 55 & 34 \\
\hline 2010 & 47 & 46 & 49 & 51 & 31 \\
\hline 2011 & 44 & 43 & 46 & 48 & 29 \\
\hline 2012 & 42 & 41 & 44 & 46 & 28 \\
\hline
\end{tabular}

\begin{tabular}{|l|l|l|l|l|l|}
\hline 2013 & 40 & 39 & 42 & 44 & 39 \\
\hline 2014 & 39 & 37 & 40 & 43 & 37 \\
\hline 2015 & 37 & 35 & 39 & 41 & 35 \\
\hline 2016 & 34 & 33 & 36 & 38 & 23 \\
\hline 2017 & 33 & 32 & 34 & 37 & 23 \\
\hline
\end{tabular}

Source: SRS 2013,SRS 2016, SRS 2019

Figurel shows the inequities variation in rural urban IMR trends in India.IMR trends in rural area (37 per 1000 live births) is significantly higher than that of urban area (23) over the Three decades. However, significant decline in IMR trends has been observed both in rural and urban areas over the years.

\section{INTER-STATE VARIATION AND INEQUALITIES IN HEALTH OUTCOIMES}

The gross inequalities in health within and between the countries presents a challenges of the world(Marmot2005).It is well known that IMR is a sensitive indicator for socioeconomic and health services development. As Deogankar's (2009) analysis shows the infant mortality rate in the poorest 20 per cent of population is 2.5 times higher than that in the richest 20 per cent of the population.A child in the low standard of living economic group is almost four times more likely to die in childhood than a child in the 'High standard of living' group. A female child is 1.5 times more likely to die before reaching her fifth birthday as compared to male child.

Table 3: Selected Health Outcomes In India And Major States

\begin{tabular}{|c|c|c|c|c|c|c|c|c|c|}
\hline States & \begin{tabular}{|l|} 
LEB \\
$(2013-2017)$
\end{tabular} & \begin{tabular}{|l|} 
IMR \\
SRS \\
2019 \\
\end{tabular} & \begin{tabular}{|l} 
U5MR \\
(2017)
\end{tabular} & \begin{tabular}{|l|} 
TFR \\
$(2019$ \\
SRS $)$ \\
\end{tabular} & $\begin{array}{l}\text { Poverty } \\
\text { level }\end{array}$ & \begin{tabular}{|l|} 
Total \\
literacy \\
Rate \\
\end{tabular} & \begin{tabular}{|l|} 
Per capita \\
NSDP \\
$(2017)$ \\
\end{tabular} & \begin{tabular}{|l} 
Per capita health \\
expenditure \\
$(2018)$
\end{tabular} & \begin{tabular}{|l|} 
HDI \\
value \\
$(2018)$
\end{tabular} \\
\hline 1 & 2 & 3 & 4 & 5 & 6 & 7 & 8 & 9 & 10 \\
\hline India & 69.0 & 33 & 37 & 2.2 & 21.9 & 73 & 82229 & 3826 & .647 \\
\hline Andhra Pradesh & 69.7(9) & $32(14)$ & $35(12)$ & $1.6(2)$ & $9.2(6)$ & $67(16)$ & $550584(8)$ & $1013(12)$ & $0.650(12)$ \\
\hline Bihar & $68.9(13)$ & $35(15)$ & $41(14)$ & $3.2(19)$ & $33.7(17)$ & $61.8(19)$ & $340512(14)$ & $491(19)$ & $0.576(20)$ \\
\hline Chhattisgarh & $65.2(18)$ & $38(16)$ & $47(17)$ & $2.4(14)$ & $39.9(20)$ & $86(4)$ & $200453(16)$ & $1354(6)$ & $0.613(15)$ \\
\hline \begin{tabular}{|l|} 
Delhi \\
\end{tabular} & 74.7(2) & $16(3)$ & $21(3)$ & $1.5(1)$ & $39.3(19)$ & $86.2(3)$ & $529739(9)$ & $1992(4)$ & $0.746(3)$ \\
\hline Goa & - & $9(1)$ & - & - & $9.9(7)$ & 88.7(2) & $51878(20)$ & $3643(1)$ & $0.761(2)$ \\
\hline Gujarat & $69.7(10)$ & $30(12)$ & $33(10)$ & $2.2(12)$ & $5.1(1)$ & $78(8)$ & $1036859(3)$ & $1189(8)$ & $0.672(11)$ \\
\hline Haryana & $69.7(11)$ & $30(13)$ & $35(13)$ & $2.2(13)$ & $16.6(12)$ & 75.4(11) & $477834(11)$ & $1119(11)$ & $0.708(6)$ \\
\hline Himachal Pradesh & $72.6(4)$ & $22(7)$ & 25(7) & $1.6(3)$ & $11.2(9)$ & $82.8(5)$ & $101534(18)$ & 2667(2) & $0.725(4)$ \\
\hline Jammu And Kashmir & $74.1(3)$ & $23(8)$ & $24(5)$ & $1.6(4)$ & $8.1(3)$ & $67.2(15)$ & $91666(19)$ & $2359(3)$ & $0.688(9)$ \\
\hline Jharkhand & $68.6(14)$ & $29(11)$ & $34(11)$ & $2.5(15)$ & $10.3(8)$ & $66.4(17)$ & 204423(17) & $866(15)$ & $0.599(18)$ \\
\hline Karnataka & $69.2(12)$ & $24(9)$ & $28(9)$ & $1.7(8)$ & $37(18)$ & 75.4(11) & 976948(5) & $1124(10)$ & $0.682(10)$ \\
\hline Kerala & 75.2(1) & $10(2)$ & $12(1)$ & $1.7(9)$ & $20.9(14)$ & 94(1) & $513322(10)$ & $1463(5)$ & $0.806(1)$ \\
\hline Madhya Pradesh & $66.0(17)$ & $47(20)$ & $55(19)$ & $2.7(17)$ & $7.1(2)$ & $69.3(13)$ & $461903(12)$ & $716(18)$ & $0.606(17)$ \\
\hline Maharashtra & $72.5(5)$ & $19(5)$ & $21(4)$ & $1.7(10)$ & $31.6(15)$ & $82.3(6)$ & $1794123(1)$ & $1011(13)$ & $0.696(8)$ \\
\hline Orissa & $68.4(16)$ & $41(18)$ & $47(18)$ & $1.9(11)$ & $18.9(13)$ & $72.9(12)$ & $327805(15)$ & $927(14)$ & $0.606(16)$ \\
\hline Punjab & 72.4(6) & $21(6)$ & $24(6)$ & $1.6(5)$ & $32.6(16)$ & $75.8(10)$ & $354830(13)$ & $1173(9)$ & $0.723(5)$ \\
\hline Rajasthan & $68.5(15)$ & $38(17)$ & $43(15)$ & $2.6(16)$ & $8.3(5)$ & $66.1(18)$ & $600433(7)$ & $927(14)$ & $0.629(14)$ \\
\hline Tamil Nadu & $71.7(7)$ & $16(4)$ & $19(2)$ & $1.6(6)$ & $8.2(4)$ & $80.1(7)$ & $1079894(2)$ & $1235(7)$ & $0.708(7)$ \\
\hline Uttar Pradesh & $65.0(19)$ & $41(19)$ & $46(16)$ & $3.0(18)$ & 14(11) & $67.7(14)$ & 979159(4) & 733(17) & $0.596(19)$ \\
\hline West Bengal & $71.2(8)$ & $24(10)$ & $26(8)$ & $1.6(7)$ & $11.3(10)$ & $76.3(9)$ & $662432(6)$ & $778(16)$ & $0.641(13)$ \\
\hline
\end{tabular}

Source: Registrar general of India Col.2Abridge life table, 2010-14 planning commission, RGI, GOI, Col.2,3SRS2016,2017, Col. 5 SRS2017, Col.6: Planning commission, Tendulkar estimates 201 1, Col. 7: Censes of India 2011. Col.10: UNDP, Human development index 2018 India state, Col.8: RBI handbook of statics 2017-18 Report, CSO., Col.9National Health Profile 2018.

Note: IMR 2017, U5MR 2017, LEB 2013-17, Total fertility rate2017, Poverty level201 1, Total literacyRate201 1.Per capita NSDP(R.S.)2017, Per capita health expenditure (crore)2018. In brackets figures ranks are given on the basis of states performance which are best and worst in the health variables.

Interstate variation in health outcomes is clear from the table 3., IMR varies from 47 in Madhya Pradesh to 9 in Goa, Under five mortality rate ranges from 12 in Kerala to 55 in Madhya Pradesh.LEB ranges from Kerala75.2 per cent which is highest in all states ranking and 65.0 per cent in Pradesh which is lowest ranking. In total fertility variable of health outcomes Delhi with 1.5 per cent are achieved first ranks and Bihar 3.2and U.P. with 3.0 per cent and followed by M.P. with 2.7 per cent at the Lowest ranking across the states. In poverty level the states Bihar(33.7) and Chhattisgarh(39.9)per cent are lowest performing.Bihar is also lower performing in per capita health expenditure and per capita NSDP variables.

In literacy rate Kerala is highest per cent 94 and Bihar is lowest per cent (61.8).

In the study concluded that there is huge variation in Indian state in terms of health outcomes in which Kerala, Goa, WestBengal, TamilNadu ,Delhi, Maharashtra are better performing states in these health outcomes and EAG states such as Bihar, Jharkhand ,U.P. Orissa,M.P. and Chhattisgarh are lower performing states. 


\section{INEQULITIES IN AVAILABILITY OF HEALTH SERVICES}

It is known that reduction in mortality and morbidity is partly due to preventive and curative intervention by public health services. The availability of services in across Indian states because of differences in socio-economic, demographic and maternal health outcomes (Baru, R. 2010).

Inequalities persistent in the availability of public health services across the selected states of India.Variations are pronounced in terms ofsocio-economic(IMR), demographic (children immunization) and maternal(institutional birth) health outcomes. In the table 4 the interstate variation are the best illustrated by comparing the state of Kerala with (10 per thousand live birth) that of best performing state in IMR andfemale literacy rate and also showed Keralastate is better position in percentage of institutional birth (96.9) and Goa is highest position in percentage of children 12-23 monthly fully immunized i.e. 88.4.and M.P. with (47 per thousand live birth are worst performer in health services indicatorsin IMR and the state Bihar is lowest performer in female literacy rate(51.2per cent) and in percentage of institutional birth the lowest position state are Jharkhand with(61.9percent). Rajasthan is the less percent51.1 in children who 12-23 monthly fully immunized. Average population served per govt. hospital the state Andhra Pradesh with highest performance and Himachal Pradesh is lowest in this position and H.P. also in lowest position in population severed per govt. hospital bed and Bihar and Andhra Pradesh are good performing. But Overall health outcomes indicators Kerala, Goa are better performing than Bihar and Andhra Pradesh Which was Worst performing and Himachal Pradesh is lowerperformers than Kerala,Goa and better performing than Bihar and Andhra Pradeshin terms of health outcomes variables.

Table:4 Inter-state Inequalities In Availability Of Health Services

\begin{tabular}{|c|c|c|c|c|c|c|}
\hline State & IMR & \begin{tabular}{|l|} 
Fema \\
le \\
Liter \\
acy \\
Rate
\end{tabular} & \begin{tabular}{|l|} 
institu \\
tion \\
Birth
\end{tabular} & $\begin{array}{l}\text { Childre } \\
\text { n 12-23 } \\
\text { monthl } \\
\text { y fully } \\
\text { immuni } \\
\text { zed }\end{array}$ & \begin{tabular}{|l|} 
Average \\
populat \\
ion \\
served \\
per \\
govt. \\
Hospita \\
l \\
\end{tabular} & $\begin{array}{l}\text { Average } \\
\text { populati } \\
\text { on } \\
\text { served } \\
\text { per govt. } \\
\text { Hospital } \\
\text { Bed }\end{array}$ \\
\hline $\begin{array}{l}\text { Andhra } \\
\text { Pradesh }\end{array}$ & 34 & 59.1 & 90.5 & 65.3 & 342484 & 3819 \\
\hline Bihar & 38 & 51.2 & 63.8 & 61.7 & 100589 & 8645 \\
\hline $\begin{array}{l}\text { Chhattisga } \\
\text { rh }\end{array}$ & 39 & 60.2 & 70.2 & 76.4 & 116397 & 2647 \\
\hline Delhi & 18 & 80.8 & 84.4 & 66.4 & 184331 & 824 \\
\hline Goa & 8 & 84.7 & 96.9 & 88.4 & 48167 & 671 \\
\hline Gujarat & 30 & 69.7 & 88.5 & 50.4 & 129270 & 1946 \\
\hline Haryana & 33 & 65.9 & 80.5 & 62.2 & 42001 & 2496 \\
\hline $\begin{array}{l}\text { Himachal } \\
\text { Pradesh }\end{array}$ & 25 & 75.9 & 76.4 & 69.5 & 8928 & 577 \\
\hline $\begin{array}{l}\text { Jammu } \\
\text { And } \\
\text { Kashmir }\end{array}$ & 24 & 56.4 & 85.7 & 75.1 & 94083 & 1066 \\
\hline Jharkhand & 29 & 55.4 & 61.9 & 61.9 & 59825 & 3079 \\
\hline Karnataka & 24 & 68.1 & 94.3 & 62.6 & 24056 & 979 \\
\hline Kerala & 10 & 92.1 & 99.8 & 82.1 & 27873 & 939 \\
\hline $\begin{array}{l}\text { Madhya } \\
\text { Pradesh }\end{array}$ & 47 & 59.2 & 80.8 & 53.6 & 170166 & 2661 \\
\hline $\begin{array}{l}\text { Maharasht } \\
\mathrm{a}\end{array}$ & 19 & 75.9 & 90.3 & 56.3 & 166880 & 2306 \\
\hline Orissa & 44 & 64 & 85.4 & 78.6 & 23729 & 2312 \\
\hline Punjab & 21 & 70.7 & 90.5 & 89.1 & 43067 & 1638 \\
\hline Rajasthan & 41 & 52.1 & 84.0 & 54.8 & 97005 & 2291 \\
\hline $\begin{array}{l}\text { Tamil } \\
\text { Nadu }\end{array}$ & 17 & 73.4 & 99.0 & 75.2 & 57297 & 899 \\
\hline
\end{tabular}

\begin{tabular}{|l|l|l|l|l|l|l|}
\hline $\begin{array}{l}\text { Uttar } \\
\text { Pradesh }\end{array}$ & 43 & 57.2 & 67.8 & 51.1 & 47782 & 2904 \\
\hline $\begin{array}{l}\text { West } \\
\text { Bengal }\end{array}$ & 25 & 70.5 & 75.2 & 84.4 & 58697 & 1170 \\
\hline India & 34 & 64.6 & 78.9 & 62.0 & 55591 & 1844 \\
\hline
\end{tabular}

SOURCE:CENTRAL BUREAU OFHEALTH INTELLIGENCE, MINISTRY OF HEALTH AND FAMILY WELFARE, GOI NHP 2018. NFHS- 4 (2015-16), Column4 data from censes of India 2011, column -2,3 SRS 2015,2016, column 5,6 NFHS-4, Column 7,8 National health profile (2018).

Note: IMR(per 1000 live birth)2015, Female Literacy Rate(percent)2011, Percentage of institution Birth(2015-16), Children 12-23 monthly fully immunized(2015-16), Average population served per govt..Hospital and Average population served per govt. Hospital 2017.

\section{INEQUALITIES IN UTILIZATION OF PREVENTIVE AND CURATIVE SERVICES}

The inequalities explained by availability and more importantly by the accessibility and quality of services provided(Baru 2010). This study shows the inter-state variation in the effectiveness of preventive service delivery. It shows a clear north south divide in the inequality of services delivered. The overall indicators for full immunization are poor in India with variation across rural and urban areas in the selected states of India.

Table: 5 Inequality In Children And Maternal Health Services Indicators Across Inter-state.

\begin{tabular}{|l|l|l|l|l|l|l|}
\hline & \multicolumn{5}{|l}{ Full immunization } & \multicolumn{3}{l}{$\begin{array}{l}\text { Mother who received } \\
\text { the at least 4 ANC } \\
\text { visit }\end{array}$} \\
\hline State & Rural & Urban & Total & Rural & Urban & Total \\
\hline $\begin{array}{l}\text { Andhra } \\
\text { Pradesh }\end{array}$ & 50.4 & 53.6 & 65.3 & 75.1 & 79.6 & 76.3 \\
\hline Bihar & 61.9 & 59.7 & 61.7 & 13.0 & 26.3 & 14.4 \\
\hline Chhattisgarh & 74.3 & 84.9 & 76.4 & 55.7 & 71.1 & 59.1 \\
\hline Delhi & 66.2 & - & 66.4 & - & 68.8 & 68.6 \\
\hline Goa & 90.1 & 87.7 & 88.4 & 90.6 & 86.2 & 89.0 \\
\hline Gujarat & 50.4 & 50.4 & 50.4 & 63.0 & 80.5 & 70.5 \\
\hline Haryana & 65.1 & 57.0 & 62.2 & 42.6 & 49.3 & 45.1 \\
\hline $\begin{array}{l}\text { Himachal } \\
\text { Pradesh }\end{array}$ & 69.9 & 64.8 & 69.5 & 67.3 & 90.2 & 69.1 \\
\hline $\begin{array}{l}\text { Jammu And } \\
\text { Kashmir }\end{array}$ & 72.9 & 81.6 & 75.1 & 78.8 & 89.2 & 81.4 \\
\hline Jharkhand & 60.7 & 67.0 & 61.9 & 69.4 & 75.6 & 72.2 \\
\hline Karnataka & 64.8 & 59.8 & 62.6 & 70.9 & 69.5 & 70.3 \\
\hline Kerala & 82.0 & 82.2 & 82.1 & 91.7 & 88.4 & 90.1 \\
\hline $\begin{array}{l}\text { Madhya } \\
\text { Pradesh }\end{array}$ & 50.2 & 63.0 & 53.6 & 29.6 & 51.6 & 35.7 \\
\hline Maharashtra & 55.8 & 56.7 & 56.3 & 69.4 & 75.6 & 72.2 \\
\hline Orissa & 79.2 & 75.0 & 78.6 & 60.6 & 69.7 & 62.0 \\
\hline Punjab & 89.3 & 88.7 & 89.1 & 67.8 & 69.4 & 68.5 \\
\hline Rajasthan & 53.1 & 60.9 & 54.8 & 34.1 & 53.8 & 38.5 \\
\hline Tamil Nadu & 66.8 & 73.3 & 75.2 & 81.0 & 81.3 & 81.2 \\
\hline Uttar Pradesh & 50.4 & 53.6 & 51.1 & 21.7 & 43.3 & 26.4 \\
\hline West Bengal & 87.1 & 77.7 & 84.4 & 75.8 & 78.1 & 76.5 \\
\hline $\begin{array}{l}\text { India/ } \\
\text { Average }\end{array}$ & 61.3 & 63.9 & 62.0 & 44.8 & 66.4 & 51.2 \\
\hline Source:NFS & & & & & & \\
\hline
\end{tabular}

Source:NFHS-4

Note: Percentage of children 12-23 months fully immunized (BCG, measles and 3 doses each of polio/DPT)201516.Mother who received the at least 4 ANC visit (2015-16).

In the table in India 61.3 percent children are fully immunized in rural areasand 63.9 percent in urban areas. Goa with 90.1 per cent with high performing state or less inequalities in rural areas and worst performing state is M.P. with 52.2 per cent it means that more inequalities inchildren full immunized 
health services in the state of M.P.On the other hand, Punjab with(88.7 per cent) is better performing state in preventive and curative health services health services and Gujarat with 50.4 per cent is worst performing state inutilization preventive and curative health services. On the other side the mother who received the 4 ANC Visit which are 51.2 per cent in average India.In variation across the state Kerala with 91.7 per cent high performer in ANC visit and followed by Goa with 90.6 and TamilNadu with 81.0 per cent. Bihar with 13 per cent in the lower position and U.P.(21.7)and Rajasthan(34.1 per cent) are the following state by Bihar.

\section{RESULTS OF THE STUDY}

In order to capture the association among the health outcomes variables of 20 major states of India spearman's rank correlation have been calculated. The correlation has been shown among Life expectancy at birth (2013-17), infant mortality rate and U5MR (2017), total fertility rate (2017), poverty level (2011), per capita net state domestic product (2016-17), total literacy rate (2011), per capita health expenditure (2018) and HDI value (2018). Results showed the significant correlation among the health outcomes. The rank correlation between LEB and per capita NSDP, total literacy rate, per capita health expenditure and HDI value show highly statistically significant correlations. Negative sign between LEB and poverty level depicts the inverse relationship between them, showing an increase in poverty level is expected to bring a fall in LEB. Increase in LEB will be reflected on HDI value, as life expectancy is an important component of HDI. Here the positive association of poverty level with IMR and U5MR

Table4: Health Outcomes And Socio-economic Factors: Correlation Matrix

\begin{tabular}{|c|c|c|c|c|c|c|c|c|c|}
\hline & LEB & IMR & $\begin{array}{l}\mathrm{U} 5 \mathrm{M} \\
\mathrm{R}\end{array}$ & TFR & \begin{tabular}{l|} 
Pove \\
rty \\
level
\end{tabular} & $\begin{array}{l}\text { Total } \\
\text { litera } \\
\text { cy } \\
\text { rate }\end{array}$ & \begin{tabular}{|l|} 
Per \\
capita \\
NSDP \\
\end{tabular} & \begin{tabular}{|l|} 
Per \\
capita \\
health \\
expe \\
nditur \\
e \\
\end{tabular} & $\begin{array}{l}\text { HDI } \\
\text { valu } \\
\text { e }\end{array}$ \\
\hline LEB & 1 & $\begin{array}{l}-.90 \\
7 * * \\
(.00 \\
0)\end{array}$ & \begin{tabular}{|l|}
. .92 \\
$8 * *$ \\
$(.00$ \\
$0)$ \\
\end{tabular} & \begin{tabular}{l|}
-.804 \\
$* *$ \\
$(.000$ \\
)
\end{tabular} & $\begin{array}{l}-.076 \\
(.763 \\
)\end{array}$ & $\begin{array}{l}.484 * \\
(.042 \\
)\end{array}$ & \begin{tabular}{|l|}
.071 \\
$(.779)$
\end{tabular} & \begin{tabular}{|l|}
$.553^{*}$ \\
$(.017)$
\end{tabular} & $\begin{array}{l}.853 * \\
* \\
(.000 \\
)\end{array}$ \\
\hline IMR & & 1 & \begin{tabular}{|l|}
.841 \\
$* *$ \\
$(.00$ \\
$0)$
\end{tabular} & $\begin{array}{l}.795 * \\
* \\
(.000 \\
)\end{array}$ & $\begin{array}{l}-.137 \\
(.565 \\
)\end{array}$ & $\begin{array}{l}.548^{*} \\
(.010 \\
)\end{array}$ & \begin{tabular}{|l|}
-.106 \\
$(.647)$
\end{tabular} & \begin{tabular}{|l|}
$-.598 *$ \\
$*$ \\
$(.004)$
\end{tabular} & $\begin{array}{l}-.861 \\
* * \\
(.000 \\
)\end{array}$ \\
\hline U5MR & & & 1 & $\begin{array}{l}.533 * \\
(.015 \\
\end{array}$ & $\begin{array}{l}-.191 \\
(.419 \\
)\end{array}$ & $\begin{array}{l}-.629 \\
* * \\
(.003 \\
)\end{array}$ & \begin{tabular}{|l|}
-.111 \\
$(.642)$
\end{tabular} & $\begin{array}{l}-.289 \\
(.217)\end{array}$ & $\begin{array}{l}-.815 \\
* * \\
(.000 \\
)\end{array}$ \\
\hline TFR & & & & 1 & $\begin{array}{l}.059 \\
(.804 \\
)\end{array}$ & $\begin{array}{l}-.379 \\
(.100 \\
)\end{array}$ & \begin{tabular}{|l|}
-.204 \\
$(.389)$
\end{tabular} & $\begin{array}{l}-.663 * \\
* \\
(.001)\end{array}$ & $\begin{array}{l}-.797 \\
* * \\
(.000 \\
)\end{array}$ \\
\hline \begin{tabular}{|l|} 
Poverty \\
level
\end{tabular} & & & & & 1 & $\begin{array}{l}.332 \\
(.142 \\
)\end{array}$ & \begin{tabular}{|l|}
-.166 \\
$(.471)$
\end{tabular} & \begin{tabular}{|l|}
-.092 \\
$(.693)$
\end{tabular} & $\begin{array}{l}.050 \\
(.833 \\
)\end{array}$ \\
\hline \begin{tabular}{|l|} 
Total \\
literacy \\
Rate
\end{tabular} & & & & & & 1 & \begin{tabular}{|l|}
-.073 \\
$(.752)$
\end{tabular} & \begin{tabular}{|l|}
392 \\
$(.078)$
\end{tabular} & \begin{tabular}{|l}
$.766 *$ \\
$*$ \\
$(.000$ \\
)
\end{tabular} \\
\hline \begin{tabular}{|l} 
Per \\
capita \\
NSDP \\
\end{tabular} & & & & & & & 1 & \begin{tabular}{|l|}
-.225 \\
$(.326)$
\end{tabular} & $\begin{array}{l}-.016 \\
(.947 \\
)\end{array}$ \\
\hline \begin{tabular}{|l|} 
Per \\
capita \\
health \\
expend \\
iture
\end{tabular} & & & & & & & & 1 & $\begin{array}{l}.730 \\
(.000 \\
)\end{array}$ \\
\hline
\end{tabular}

\section{HDI}

value

Note: ** Correlation is significant at the 0.01 level (2 tailed), * Correlation is significant at the 0.05 level ( 2 tailed)

The negative association IMR and per capita health expenditure is because of the fact that the rise in per capita health expenditure is because of the fact that the rise in per capita health expenditure will ensure better health status, which is expressed to be reflected on health outcomes such as IMR. The same is true for U5MR also. Literacy rate also shows an inverse relation with IMR and U5MR. Higher level of population literacy makes people conscious about the health of their children which ensure reduction in IMR and U5MR(Amonker and Brinker 1997).

To test the significance of rank correlation coefficients of different indices for different states, 't'statistics has been carried out to calculate the empirical ' $t$ ' value.

Table: 5 Test Of Significance For Rank Correlations

\begin{tabular}{|l|l|l|l|}
\hline $\begin{array}{l}\text { Rank } \\
\text { correlation } \\
\text { between } \\
\text { variables }\end{array}$ & $\begin{array}{l}\text { Empirical } \\
\text { t value }\end{array}$ & $\begin{array}{l}\text { Significance } \\
\text { Level }\end{array}$ & $\begin{array}{l}\text { Null } \\
\text { Hypothesis }\end{array}$ \\
\hline IMR and U5MR & 4.10 & $\begin{array}{l}\text { Significant at } \\
\text { five percent }\end{array}$ & Rejected \\
\hline $\begin{array}{l}\text { IMR and Per } \\
\text { capita NSDP }\end{array}$ & 3.54 & $\begin{array}{l}\text { Significant at } \\
\text { five percent }\end{array}$ & Rejected \\
\hline $\begin{array}{l}\text { IMR and Per } \\
\text { capita health } \\
\text { expenditure }\end{array}$ & 2.39 & $\begin{array}{l}\text { Significant at } \\
\text { five percent }\end{array}$ & Rejected \\
\hline $\begin{array}{l}\text { LEB and HDI } \\
\text { LEB and Per } \\
\text { Capita NSDP }\end{array}$ & 3.037 & $\begin{array}{l}\text { Significant at } \\
\text { five percent }\end{array}$ & Rejected \\
\hline $\begin{array}{l}\text { IMR and } \\
\text { Literacy Rate }\end{array}$ & 2.28 & $\begin{array}{l}\text { Significant at } \\
\text { five percent }\end{array}$ & Rejected \\
fignificant at & Rejected \\
\hline $\begin{array}{l}\text { Health } \\
\text { Expenditure } \\
\text { and HDI }\end{array}$ & 3.70 & $\begin{array}{l}\text { Significant at } \\
\text { five percent }\end{array}$ & Rejected \\
\hline $\begin{array}{l}\text { Health } \\
\text { expenditure } \\
\text { and NSDP }\end{array}$ & 2.21 & $\begin{array}{l}\text { Significant at } \\
\text { five percent }\end{array}$ & Rejected \\
\hline
\end{tabular}

From the table 5 it is clear that in the health outcomes variables association null hypothesis is rejected and alternative hypothesis is accepted as the absolute value of empirical ' $t$ ' value is greater than the tabulated ' $t$ ' value and showed significant difference in the ranking of the states given on the basis of health outcomes variables.

\section{CONCLUSION AND POLICY SUGGESTION}

The present study has been an effort to illustrate the trends and interstate variation in health outcomes in India. Infant mortality is widely accepted indicator of well being and is accepted as a key indicator of social progress and economic development. Health outcomes in India have been showing trends of improvements over a period of time. Infant mortality has declined significantly and at the same time life expectancy at birth has been continuing its upward climb. The study indicates that there is a huge variation between northern and southern states of India in respect of demographic behavior. The southern states are highly advanced in demographic parameters, while the EAG states are at the bottom of the spectrum. The study results revealed the rank correlation between LEB and poverty level, per capita NSDP, total literacy rate, per capita health expenditure and HDI value show highly statistically significant correlation. Human Development Index(HDI) value and Life expectancy at birth (LEB) also showed the rank correlation has been highly statistically positively significant correlations. Negative sign of rank correlation between Life expectancy at 
birth(LEB) and poverty level depicted the inverse relationship between them. The study also revealed the inequalities in utilities of health services in which showed the variations across the rural-urban areas in the state of India.

\section{REFERENCES}

1. Amonker, R.G. and G.D. Brinker, "Determinants of Infant and Child Mortality in India, Internal Review of Modern Sociology,(1997) Vol. 27, No. 2, pp. 1-22.

2. Baru, "Inequities in access to health services in India: Caste class and region," Economic and political weekly, (2010) vol xlv no38,pp 49-58.

3. Bose, "India is disturbing Health Card," Economic and political weekly,(2008) vol. 42, no50,ppl0-13.

4. Baru, "Health services Inequities as Challenge to Health Security "Oxfam IndiaWorking paper series, (2010) OIWPS.

5. Banerjee, Abhijit and E. Dulflo, "Health Care Delivery in Rural Rajasthan", Economic and PoliticalWeekly, (2004)Vol.39, No.9,pp.9449-949.

6. Choudhary, "Determinants of Infant Mortality Rate in Rajasthan" Indian economic association, specials issues, 2015 pp. 180-200.

7. Kurian, N.J.,." issues of health equity in India" India social development report 2010, The land Question and marginalized , Council for social development ,(2010) Oxford university press

8. Marmot M, "Social determinants of health inequalities,"public health,(2005)vol 365.

9. Malhotra, "Health and development" Economics of Education and Health, The Indian economic association Delhi(2008).

10. NFHS 4, "International Institute of Population Sciences(IIPS)" National family health survey, (2015-16) Ministry of Home Affairs, GOI Mumbai.

11. NHP, "Central Bureau ofHealth Intelligence,"Ministry of Health and family welfare2018,GOI.

12. Strauss and Thomas, "Health Nutrition and Economic Development," Journal of Economic Literature, (1998)vol.36no2, pp 766-817.

13. SRS, "SRS bulletin Registrar general of India's Ministry of home affairs GOI(2013), vol48 no2 newDelhi.

14. Roser M., Hannah Ritchie and Bernadette Dadonaite2019, "Childs and infant mortality," Our World in Data. Statistics and research Coronavirus Pandemic (COVID-19).

15. UNITED Nations Report 2017, "Voluntary National Review Report on the implementation of Sustainable Development goals". NewYork 2017. 